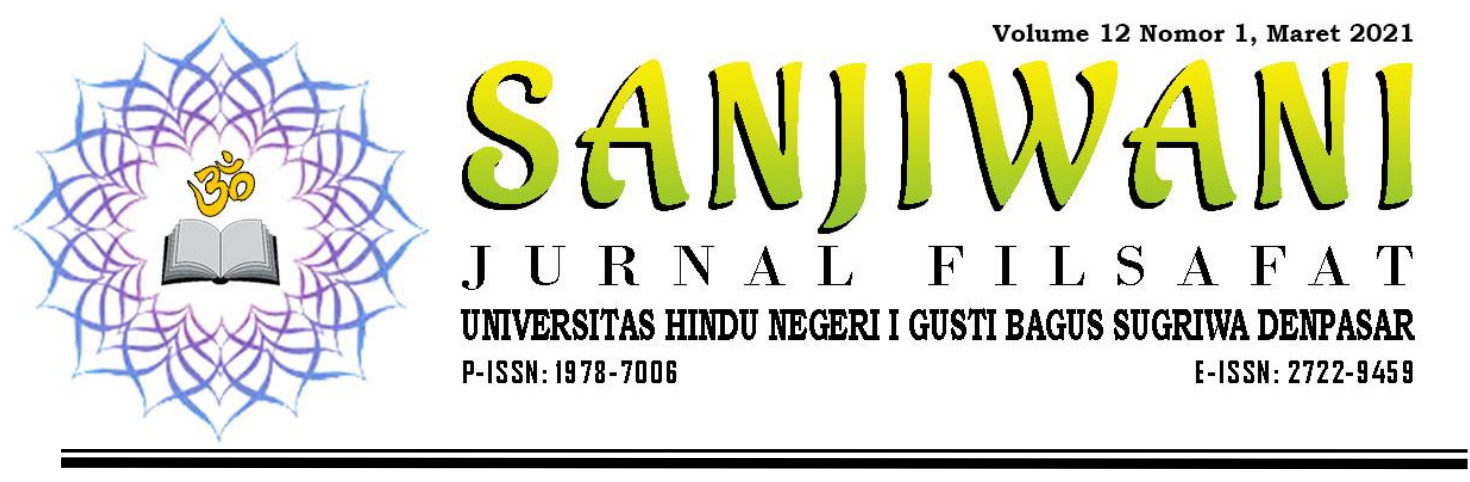

\title{
Advaita Brahmajũāna (Kesatuan Ātman Dengan Brahman) (Kajian Teo-Filosofi)
}

\author{
Putu Dana Yasa \\ World Hindu Parisad \\ putu.dyasa@gmail.com
}

\begin{tabular}{|c|c|}
\hline Keywords: & ABSTRACT \\
\hline Advaita & The Advaita Brahmajñana is one of the teachings conveyed in \\
\hline Brahmajūāna; & the Agni Purana. This knowledge is knowledge that gives human \\
\hline Teo-philosophy & beings awareness that all the elements in this universe are atma, \\
\hline & s Brahman itself. Ātma and Brahman are inseparable \\
\hline & entities, àtma gi \\
\hline & intervention of Brahman himself. Advaita Brahmajñāna is a science \\
\hline & $\begin{array}{l}\text { that explains how humans are able to improve their quality so that } \\
\text { they can manifest the existence of ätma in themselves. Realizing }\end{array}$ \\
\hline & $\begin{array}{l}\text { that all existing beings are Brahma or God is the pinnacle of human } \\
\text { level to manifest the existence of God. }\end{array}$ \\
\hline
\end{tabular}

\begin{tabular}{|c|c|}
\hline Kata Kunci & ABSTRAK \\
\hline $\begin{array}{l}\text { Advaita } \\
\text { Brahmajñāna; } \\
\text { Teo-Filosofi }\end{array}$ & $\begin{array}{l}\text { Advaita Brahmajñāna adalah salah-satu pengetahuan } \\
\text { yang disampaikan dalam Agni Purana. Pengetahuan ini } \\
\text { merupakan pengetahuan yang memberikan kesadaran pada } \\
\text { manusia bahwa seluruh elemen yang ada pada alam semesta } \\
\text { ini adalah ātma, dan ātma adalah Brahman itu sendiri. Ātma } \\
\text { dan Brahman merupakan satu kesatuan yang tidak dapat } \\
\text { dipisahkan, ātma memberikan kehidupan pada setiap } \\
\text { makhluk yang ada dan seluruhnya adalah campur tangan } \\
\text { dari Brahman itu sendiri. Advaita Brahmajñāna merupakan } \\
\text { sebuah pengetahuan yang menjelaskan bagaimana manusia } \\
\text { mampu meningkatkan kualitas diri sehingga mampu } \\
\text { menyadari keberadaan ātma dalam dirinya. Menyadari } \\
\text { bahwa semua makhluk yang ada adalah Brahma atau Tuhan } \\
\text { adalah puncak dari pada tingkatan manusia dalam upaya } \\
\text { menyadari keberadaan Tuhan. }\end{array}$ \\
\hline
\end{tabular}




\section{PENDAHULUAN}

Keyakinan umat Hindu terhadap keberadaan $\bar{a} t m a$ yang merupakan bagian dari Tuhan atau Brahman itu sendiri menjadi dasar yang kokoh meyakini bahwa segala yang ada dan akan ada tidak terlepas dari kemahakuasaan Ida Sang Hyang Widhi Wasa sebagai asal mula dan juga akhir dari alam semesta. Ātma merupakan bagian atau percikan terkecil dari Ida Sang Hyang Widhi yang memberikan kehidupan bagi setiap makhluk di dunia ini. Kegaiban atau kekuatan àtma menjadi sumber kekuatan utama setiap makhluk untuk dapat memperoleh kehidupan.

Sebagai percikan dari Tuhan, tentunya sifat dari pada àtma pada dasarnya memiliki kemurnian yang sama dengan Tuhan itu sendiri. Namun setelah berada dalam tubuh makhluk khususnya manusia mendapatkan pengaruh maya sehingga kemurnian àtma sebagai bagian dari Tuhan dipengaruhi oleh sifat-sifat keduniawian yang cenderung malah mengarahkan manusia semakin jauh dari Tuhan. Manusia pada dasarnya harus menyadari bahwa bagian terkecil dari Tuha yang disebut dengan ātma adalah tidak lain merupakan Tuhan atau Brahman itu sendiri.

Ilmu yang mempelajari pemahaman tentan ätma dikenal dengan istilah àtma tattwa. Sedangkan dalam pustaka suci upanisad kata ātma diakatakan berasal dari kata "an" artinya bernafas, hidup". Dengan bernafas itu hidup, jadi nafas itu adalah suatu kehidupan (Sujana,dkk. 2010:34). Sehingga secara sederhana disimpulka bahwa àtma sebagai sumber yang memberikan kehidupan kepada manusia dan àtma itu sendiri asalnya adalah bersumber dari pada Brahman.

Meyakini keberadaan Brahman dan ätma merupakan dasar yang harus dimiliki umat Hindu untuk memperkokoh sraddha dan bhakti sebagai manusia. Agar dapat mencapai Brahman yang tertinggi harus mampu memahami ätma yang berada pada diri sendiri terlebih dahulu, ketika telah mampu melakukan hal tersebut maka manusia tersebut akan memahami hakikat sesungguhnya sebagai manusia dalam kehidupan ini.

Penyatuan àtma dan Brahman menjadi tujuan tertinggi umat Hindu, hal ini tercapai apabila manusia telah benar-benar mampu menaklukan seluruh sifat avidya yang terdapat dalam dirinya. Ajaran mengenai konsep-konsep untuk dapat mencapai penyatuan dengan Brahman telah dituangkan dalam pustaka suci Hindu sebagai bagian dari konsep teologi yang dimiliki umat Hindu. Namun, realitanya jika dilihat dari sudut pandang atau perspektif berbeda dalam hal ini hal ini sangat sulit untuk dilakukan karena membutuhkan kemurnian yang tinggi untuk dapat mencapai Brahma.

Salah-satu ajaran yang menuangkan konsep tentang kesatuan antara ätma dengan Brahman tertuang dalam ajaran Agni Purana. Dalam Agni Purana sebagai salah-satu bagian dari delapan belas purana yang ada, didalamnya tertuang ajaran-ajaran mengenai tidak terpisahnya antara ātma dengan Brahman. Konsep ini disebut dengan Advaita Brahmajñannan atau kesatuan antara ätma dengan Brahman. Brahman adalah jiwa ilahi sedangkan Brahmajñanna adalah pengetahuan tentang Brahman. Advaita berarti satu. Sehingga secara etimologi Advaita Brahmajñana adalah pengetahuan yang mengajarkan kesatuan antara individu (ātman) dengan Brahman (Sanjaya, 2001: 2). 
Pemahaman tentang kesatuan àtman dengan Brahman tentunya sangat penting dipahami oleh umat Hindu dalam upaya mencapai kebebasan tertinggi dan terlepas dari kesengsaraan terlahir sebagai manusia di bumi ini. Untuk mempu mencapai hal tersebut hal terpenting yang harus dipahami dan dilakukan adalah mampu mengenal dan menaklukan sang diri. Memahami sang diri bukan hanya sekedar mengetahu diri yang penuh dengan keterikatan duniawi, namun mampu melepaskan ikatan tersebut dan memahami hakikat diri jauh lebih mendalam sehingga menemukan bahwa sang diri adalah bagian dari Brahman atau Tuhan itu sendiri.

Sebagai agama yang dikatakan ajarannya memiliki sifat yang logis atau mampu diterima oleh akal sehat pikiran manusia, ajaran mengenai konsep tidak terpisahnya antara ätma dengan Brahman tentu mejadi menarik untuk dikaji bukan hanya dalam sudut pandang teogis namun juga dalam kajia filosofis yang tujuan utamanya tidak lain adalah memuliakan ajaran yang tertuang dalam berbagai teks atau pustaka suci itu sendiri.

\section{PEMBAHASAN}

\subsection{Konsep tentang $\bar{A}$ tma dan Brahman}

Umat Hindu pada umumnya memiliki dasar keyakinan atau Sradhha yang digunakan sebagai pijakan dari upaya menganal Tuhan secara menyeluruh. Ajaran ini secara mendalam tertuang dalam konsep Pañca Śraddā. Dua diantara kelima bagian dari Sraddha tersebut adalah meyakini keberadaan Tuhan atau Brahman (Widhi Śraddhā) dan percaya akan adanya Ātma sebagai sumber yang menghidupi diri manusia. Ātma yang berada dalam diri manusia biasanya dikelan dengan istilah jiwatman.

Konsep mengenai àtma pada dasarnya telah tertuang dalam berbagai pustaka suci Hindu yang secara keseluruhan pada dasarnya menguraikan bahwa asal dari pada àtma sesungguhnya adalah Brahman itu sendiri. Sebagai bagian yang berasal dari Brahman tentunya suatu saat àtma harus kembali pada Brahman. Hal inilah yang sesungguhnya dapat dikatakan sebagai tugas utama manusia untuk dapat menghantarkan àtma menyatu dengan Brahman.

$\bar{A}$ tma sebagai bagian dari Tuhan yang murni tentunya memiliki kemurnian yang berbeda dengan badan kasar manusia, àtma yang berada dalam diri manusia sesungguhnya tidak terpengaruh terhadap segala keinginan indriaindria manusia walaupun pada dasarnya àtma merasakan segalanya dan memahami segala yang dilakukan oleh manusia. Dalam sudut pandang teologi hal ini tertuang dalam Chāndogya Upanisad VIII.7.1 yang menjelaskan sebagai berikut:

Ya ātma apahata pātmā vijaro vimrtyur visako vijighatso 'pipāsah satya kāmah, satya samkalpah, so 'nvestavyah, so vijijñāsitavyah sa sarvāms ca lokān āpnoti sarvāms ca kāmān. Yas tam ātmānam anuvidya vijañati. Iti ha prajāpatir uvāca (Chāndogya Upanisad VIII.7.1)

Terjemahan:

$\bar{A} t m a$ bebas dari kejahatan, bebas dari tua, bebas dari kematian, bebas dari kesdihan, bebas dari lapar dan haus. Yang keinginannya adalah kebenaran. Ia dapat dicari,padanya seseorang dapat berkeinginan untuk 
memahaminya. Seseorang yang telah menemukannya dan memahaminya, ia mendapatkan dunia, seluruhnya. Demikian Prajapati berkata (Sura, 1999 : 58)

Kutipan Chāndogya Upanisad VIII.7.1 di atas memberikan pemahaman bahwa àtma yang berada dalam diri manusia tidak mendapat pengaruh pada apa yang terjadi dengan indria-indria manusia, dan juga menguraikan betapa pentingnya memahami keberadaan ātma yang berada dalam diri manusia sehingga mempu mencapai kesadaran yang tertinggi dan mampu menyatukan diri dengan sang pencipta. Penyatuan ätma dengan Brahman akan mengakhiri penderitaan terlahir berkali-kali sebagai makhluk yang berbeda di alam semesta ini, sehingga adalah kewajiban bagi setiap makhluk untuk memahami keberadaan àtma yang merupakan Brahman itu sendiri.

Kata Ātma menurut S. Radhakrishnan dalam buku yang berjudul "Panca Dhātu, Atom, Atma, dan Animisme" karangan I Ketut Donder berasal dari akar kata bahasa sanskerta " $A n$ " yang berarti bernafas, dia adalah nafas yang hidup, jiwa, diri atau oknum dari perseorangan (Donder, 2001:167). Sehingga jelas bahwa àtma sebagai bagian yang berada didalam diri manusia yang memberikan kehidupan pada semua makhluk pada alam semesta ini.

Pernyataan bahwa àtma merupakan bagian dari kehidupan setiap makhluk dikuatkan secara teologi dengan beberapa sumber yang menjelaskan bahwa àtma/ Brahman itu sendiri adalah yang memberikan kehidupan yang posisinya tidak lain adalah terletak dalam diri setiap makhluk itu sendiri. Hal ini tertuang dalam pustaka suci Bhagavadgita dan Athavaveda yang menyampaikan sebagai berikut:

Aham ātmā gudākeśa

Sarva-bhütāśaya-sthitah

Aham ādiś ca madhayam ca

Bhūtānām anta eva ca (Bhagavad Gitā X.20)

Terjemahan:

Aku adalah sang diri yang ada dalam hati setiap makhluk, wahai Gudākeśa, aku adalah permulaan, pertengah dan akhir dari mahkluk semua (Pudja, 2019 : 258)

Akāmo dhiro amrtah svayambhū rasena trpto na kutaścanonah, tameva vidyān na bibhāya mrtyorātmānaṁ dhiramajaraṁ yuvānam (Atharvaveda X.8.44)

Terjemahan:

Terbebas dari hawa nafsu keinginan, memiliki sifat bijaksana (dhira), terbebas dari kematian, dapat mengendalikan dirinya sendiri, mengenyangkan dirinya dengan persembahan berupa sari buah, tidak kekurangan suatu apapun dengan pencapaian kebijaksanaan itu, ia tidak takut lagi akan kematian dan senantiasa muda dan tidak lapuk usia (Taniputera, $2005:$ 498).

Selain kutipan sloka di atas, tentu masi banyak pustaka suci yang menjelaskan tentang keberadaan dari ätma yang merupakan bagian dari Tuhan 
yang memberikan kehidupan bagi setiap makhluk. Kemurnian àtma sebagai jiwa individual tidak memiliki nafsu, kekal, bijaksana dan sempurna dalam berbagai hal. Secara sederhana dari kutipan sloka Bhagavadgita X.20 dan Atharvaveda X.8.44 kita dapat memahami bahwa àtma sebagai percikan terkecil dari Tuhan adalah Tuhan itu sendiri. Dalam upaya memperkuat keyakinan terhadap ātma dan Brahman, perlu dipahami pula bahwa Tuhan berada di dalam dan diluar makhluk hidup sifatnya sangat halus sehingga manusia dengan penuh keterbatasan tidak memiliki kemampuan untuk mencapai hal tersebut dengan mudah.

Jika dikaji lebih mendalam dalam pandangan filsafat yang memerlukan penjelasan konkrit mengenai asal muasal dari ātma maupun Brahman tentunya tidak dapat dipungkiri bahwa ada kekuatan diluar nalar manusia yang disebut dengan Tuhan sebagai sumber dari segala yang ada maupun akan ada. Alam semesta dan kehidupan yang ada pada bumi ini tentunya tidak mungkin dilakukan oleh mahkluk biasa seperti manusia dan lainnya, tentunya ini semua terjadi melalui proses penciptaan yang melibatkan campur tangan Tuhan yang memiliki kemahakuasaan yang tinggi.

Selajutnya pengetahuan mengenai Brahman atau Tuhan pada dasarnya dipandang masuk kedalam sebuah kajian yang disebut dengan teologi. Kata teologi yang memiliki pengertian sebagai ilmu tentang Tuhan secara etimologi dipadankan dengan istilah Brahmavidya dalam keyakinan Hindu. Brahma yang memiliki arti Tuhan dan Vidya artinya pengetahahuan. Sehingga Brahmavidya sesuai jika dipadankan dengan teologi sebagai sebuah kajian untuk dapat memahami Tuhan secara mendalam. Dalam kajian Brahmavidya pengetahuan tentang Tuhan yang tidak beratribut masuk kedalam wilayah pengetahuan paravidya, pada wilayah paravidya pengetahuan tentang Tuhan disebut Nirguna Brahman sedangkan dalam wilayah aparavidya Tuhan disebut dengan Saguna Brahman.

Tuhan dalam konsep Nirguna Brahma tidak memiliki bentuk tertentu, tidak memiliki nama tertentu serta tidak dapat dibayangkan sebagai sesuatu apapun, sebab Brahman bukanlah ini dan itu (neti-neti) yang mirib dengan istilah barat Impersonal God. Selama kita memberi nama apapun, maka nama itu, entah nama suci ataupun tidak suci maka itu telah mendefinisikan Tuhan yang tak terabatas, Tuhan yang maha segalanya, ke dalam hal-hal yang terbatas. Hal ini tidak mungkin, oleh sebab itu Brahmavidya "pengetahuan tentang Tuhan" pada wilayah ini tidak mengizinkan pemujanya untuk membayangkan Tuhan sebagai apapun (Donder, 2009:33).

Penjelasan mengenai Tuhan dalam wilayah Nirguna Brahman tentunya sangat luas di bahas dalam kitab suci Hindu, hal tersbut dijelaskan dalam kitab suci Bhagavadgita sloka X.2 dan XII.5 sebagai berikut:

Na me viduh sura gaṇāh

prabhavam na maharșayah

aham ädir hi devānāìn

maharșinām ca sarvaśah (Bhagavadgita X.2)

Terjemahan: 
Baik para dewata maupun rsi agung tidak mengenal asal mula-Ku (Tuhan), sebab dalam segala hal Aku (Tuhan) adalah sumber para dewata dan rsi agung (Pudja, 2019: 246)

Sedangkan wilayah pengetahuan Saguna Brahman adalah Brahman yang sudah mendapatkan pengaruh maya yang sering juga disebut aparabrhaman. Dalam berbagai sumber khususnya lontar-lontar tatwa yang terdapat di Bali dikelan dengan istilah Sada Siwa. Dalam wilayah Saguna Brahman Tuhan juga disebut sebagai Tuhan yang imanen. Dalam Kamus Besar Bahsa Indonesia (KBBI) kata imanen berada dalam kesadaran atau dalam akal budi (pikiran). Tuhan dalam bentuk yang imanen artinya Tuhan dalam sifatnya yang terjangkau oleh akar pikiran manusia.

Diantara berbagai wilayah teologi, maka teologi Saguna Brahma atau teologi yang mengenakan kepada Tuhan berbagai macam atribut yang juga dapat disebut sebagai theology personal God, adalah wilayah teologi yang paling mudah untuk didekati oleh nalar manusia. Karena itu dalam wilayah teologi ini peran otak, nalar atau akal menjadi sangat penting dan perlu dihargai (Donder, 2009: 39).

Sebagai manusia yang memiliki keterbatasan akibat pengaruh maya yang menyeliputi seluruh indria, tentu akan sangat sulu untuk dapat memahami Tuhan dalam wilayah Nirguna Brahman. Maka dari itu, kajian mengenai Tuhan yang dapat dijangkau oleh manusia adalah terletak pada wilayah Saguna Brahman, dimana dalam wilayah tersebut Brahman telah memiliki atribut sehingga manusia dapat lebih mudah untuk dapat memahami dan menyadari keberadaan dari Tuhan itu sendiri.

\subsection{Advaita Brahmajñāna dalam Agni Purana}

Agni Purana pada umunya memberika berbagai ajaran yang tertuang didalamnya diantaranya adalah penjelasan mengenai seluruh avatara Visnu, persyaratan untuk membangun sebuah kuil, ilmu tentang astrology, ritual pengetahuan tentang obat-obatan, arsitektur, sastra, tata bahasa, dan rangkuman dari ajaran Veda dan Upanisad. Salah satu yang dijelaskan dalam Agi Purana adalah mengenai kesatuan atau tidak terpisahnya antara ätma dan Brahman. Pemahaman tentang àtma dan Brahman dalam pandangan Agni Purana pada dasarnya secara keseluruhan mengacu pada ajaran-ajaran pustaka suci Veda dan Upanisad. Dalam pandangan Agni Purana pengetahuan ini disebut dengan Advaita Brahmajñana (kesatuan antara jiwa individu/ àtma dengan Brahman.

Advaita Brahmajñanna secara etimologi dapatdiartikan sebagai pengetahuan tentang kesatuan ätma dengan Brahman. Brahman adalah jiwa ilahi dan Brahmajñaña adalah pengetahuan tentang Brahman. Sedangkan Advaita memiliki arti satu. Sehingga Advaita Brahmajñāna adalah pengetahuan yang mengajarkan kesatuan antara jiwa individu (ātma) dengan Brahman (Sanjaya, 2001:3).

Pandangan Agni Purana mengenai ätma menjeleaskan bahwa letaknya berada dalam diri manusia dan merasakan serta memahami apapun yang terjadi namun yang dirasakan tidak sama dengan perasaan fisik manusia yang diselimuti ketidaktahuan atau keterbatasan dalam Indira-indrianya. Keberadaan 
àtma didalam diri manusia menjadi obyek dari meditasi untuk dapat memahami hakikat dari sang diri sesungguhnya sehingga mampu melepaskan diri dari segala keterikatan duniawi dan mampu bersatu dengan Brahman.

Upaya untuk mencapai kebebasan tertinggi tentunya dapat dilakukan dengan berbagai cara, salah satunya adalah berupaya untuk dapat menyadari sesungguhnya siapa diri kita. Menyadari diri bukan hanya melihat diri dari bagian luar saja, melainkan masi ada bagian dari Tubuh ini yang merupakan sumber hakikat sesungguhnya terlahir sebagai manusia. Menjadi manusia memiliki kesempatan yang tinggi untuk dapat mempelajari arti dari kehidupan yang sesungguhnya dalam dunia ini.

Brahman bukanlah sesuatu yang benar atau salah. Ia bukanlah sesuatu yang berwujud atau tak terwujud. Brahman memiliki beberapa bagian, namun pada saat yang sama juga merupakan satu kesatuan. Brahman tidak dapat dilukiskan dalam media apapun. Ia juga tidak dapat dicapai dengan kekuatan perbuatan atau karma.Brahman ini senantiasa murni, ia tidak memiliki keterikatan dan senantiasa berwujud kebahagiaan. Yang diperlukan adalah sebuah perasaan atau kesadaran bahwa "aku" adalah Brahman. Aku tiada lain adalah àtma dan àtma sendiri sesungguhnya adalah Brahman (Sanjaya, 2001:92).

Memahami dan menyadari secara mandala bahwa diri ini adalah Brahman tentu merupakan hal yang tidak mudah untuk dilakukan. Sifat-sifat Brahman yang memiliki kemurnian telah dipengaruhi oleh badan kasar dari diri manusia sehingga sangat sulit untuk dapat memperoleh kemurnian itu kembali. Hal ini tentunya dapat diperoleh dengan kematangan pengetahuan spiritual yang dimiliki manusia untuk menyadari keberadaan Brahman yang berada jauh namun sangat dekat dengan diri manusia. Dalam berbagai sumber pustaka suci Hindu kesadaran terhadap keberadaan Tuhan berada dalam diri setiap makhluk bahkan dikata sebagai puncak dari kesadara manusia berteologi. Ketika mampu menyadari bahwa seluruhnya adalah Brahman maka apapun yang dilakukan oleh manusia akan selalu mengacu pada kebenaran.

Ajaran mengenai tidak terpisahnya antara ätma dengan Brahman (Advaita Brahmajūāna) dalam Agni Purana dijelaskan secara singkat melalui kisah yang disampaikan oleh Bhārata kepada seorang raja yang bernama Soubira. Hal yang diceritakan oleh Bhārata adalah kisah antara Ŗbhu (putra dari dewa Brahma) dengan Nidagha sebagai murid dari Rbhu. Sebagai seorang guru tentunya Rbhu menyampaikan segala hal yang perlu disampaikan kepada seorang murid kepada Nidagha.

Selanjutnya setalah memperoleh pengetahuan dari Rsi Rbhu, diceritakan bahwa Nidagha kemudian pergi dan tinggal disebuah kota. Setelah seribu tahun berlalu, Rsi R.bhu kemudian pergi ke kota tersebut untuk melihat perkembangan Nidagha. Melihat kedatangan gurunya tentunya Nidagha memberi hormat dan menyajikan berbagai jenis makanan untuk Rsi Rbhu. Setelah makan kemudian Nidagha bertanya kepada Rbhu "apakan anda sudah puas?" pertanyaan ini kemudian dijawab oleh Rsi Ṛbhu "apa maksudmu, pertanyaan tentang kepuasan hanya akan muncul jika aku merasa haus dan lapar. Aku adalah ātma dan ātma senantiasa merasa puas. Lalu apa gunanya menanyakan itu padaku. Aku adalah bagian dari Brahman yang maha ada dan demikian juga dengan kamu. Kau tidak 
berbeda denganku, kita berdua adalah satu dan aku dating kesini untuk memberikan pengetahuan itu kepadamu. Sekarang kau telah mengetahui bahwa Brahman berada dimana-mana maka ijinkan aku meninggalkanmu.

Setalah kepergiannya beribu tahun sebelumnya, Rsi Rbhu kemudian kembali mendatangi Nidgha, dan menemukan bahwa Nidagha tidak lagi tinggal di kota tersebut. Ia tinggal juag dari perkotaan. Rbhu kemudian bertanya kepada Nidagha "mengapa kau meninggalkan kehidupan kota" pertanyaan tersebut kemudia di jawab "karena aku tidak ingin tinggal di kota dimana ada seorang raja yang berkuasa" Rbhu kembali bertanya "siapakah raja itu, tunjukanlah padaku siapa raja itu dan siapa yang disebut sebagai rakyat".

Dengan pertanyaan tersebut Nidagha menjawab "raja adalah orang yang berkedudukan tinggi setinggi gunung. Ia adalah yang mengendaai gajah. Sedangkan mereka yang berjalan kaki di bawahnya adalah rakyatnya. Mendengar pernyataan tersebut Rsi Rbhu pun menjawab “apa maksudmu, Brahman adalah raja dan Brahman adalah gajah itu sendiri. Bagaimana kau membedakan keduanya, bagaimana kau mengatakan bahwa ada yang menunggangi yang lainnya, apakah raja itu adalah sebuah fisik atau àtma dan apakah gajah itu adalah tubuh fisiknya atau àtma, siapa yang mengendarai siapa, aku tidak paham maksudmu (Sanjaya, 2001:96-97).

Dari hasil percakapan antara Rsi Rbhu dengan muridnya Nidagha kita dapat memahami terdapat sebuah ajaran yang penuh akan nilai teologis maupun filosofis tentang apa sesungguhnya àtma dan Brahman tersebut. Seluruh alam semesta adalah Brahman, beliau adalah sumber dari segala yang ada saat ini. Bagian dari Brahman salah-satunya adalah ätma sebagai percikan terkecil yang memberikan kehidupan bagi setiap mahkluk yang ada pada alam semesta ini. Ajaran yang disampaikan oleh Rsi Ṛbhu kepada Nidagha merupakan sebuah ajaran tingkat tinggi dalam upaya memahami bahwa tidak ada satupun yang bukan àtma dan ātma tersebut adalah Brahman itu sendiri.

Pengetahuan mengenai àtma dan Brahman merupakan satu kesatuan yang tidak terpisahkan inilah yang disebut dengan Advaita Brahmajñ̄na sebagai salah satu ajaran yang memberikan pemahaman kepada manusia untuk dapat menyadari bahwa dalam setiap makhluk terdapat sebuah àtma yang didalamnya memberikan kehidupan. Ajaran ini disampaikan oleh Rsi Ṛbhu kepada Nidagha dan kemudian disampaikan kembali oleh Bhārata kepada raha Shoubhira. Ajaran ini menekankan bahwa secara keseluruhan seluruh elemen yang ada pada alam semesta ini adalah satu dan sama. Akibat dipengaruhi oleh sifat maya dan ketidaktahuan manusia yang menimbulkan perbedaan dari seluruh yang ada pada alam semesta ini.

\section{PENUTUP}

Ajaran tentang àtma dan Brahman tertuang dalam berbagai pustaka suci Veda sebagai sumber acuan dalam meningkatkan sradhha dan bhakti manusia kepada Ida Sang Hyang Widhi. Ātma dan Brahman adalah satu. Salah satu sumber acuan untuk dapat meyakini bahwa àtma dan Brahman merupakan satu kesatuan dan bukan hal yang berbeda terdapat dalam ajaran yang disampaikan dalam Agni Purana. Dalam ajaran Agni Purana disampaikan sebuah ajaran tentang 
hakikat diri yang didalamnya terdapat sebuah ātma yang memberikan kehidupan pada manusia, ajaran ini disebut dengan Advaita Brahmajñāna atau pengetahuan tentang satu kesatuan antara ätma dengan Brahman.

Dalam Agni Purana disampaikan kisah antara Rsi Rbhu yang menyampaikan pengetahuan tersebut pada muridnya yang bernama Nidagha, dan ajaran ini kembali disampaika oleh Bhātara kepada seorang raja yang bernama Shoubhira. Ajaran ini tentunya harus dipahami oleh seluruh umat Hindu untuk dapat melepaskan diri dari ilusi tentang perbedaan dari seluruh yang ada pada alam semesta ini.

\section{DAFTAR PUSTAKA}

Donder, I Ketut. 2001. Pañca Dhātu, Atom, Ātma dan Animisme (Sebuah evolusi tentang sesuatu yang amat kecil sebagai asas hidup dan kehidupan. Surabaya: Paramita

Donder, I Ketut. 2009. Teologi Memasuki Gerbang Ilmu Pengathuan Ilmiah Tentang Tuhan Paradigma Sanatana Dharma. Surabaya. Paramita

Pudja, G. 2019. Bhagavad Gitā (Pañcama Veda). Surabaya: Paramita

Sanjaya, Gede Oka. 2001. Agni Purana. Surabaya: Paramita

Sujana, I Made, dkk. 2010. Bahan Ajar Tattwa. Kementerian Agama Republik Indonesia Direktur Jenderal Bimbingan Masyarakat Hindu

Sura. 1999. Siwa Tattwa. Milik Pemerintah Provinsi Bali, Peningkatan Sarana dan Prasarana Kehidupan Beragama

Taniputera, Ivan. 2005. Atharvaveda Samihitā II Bhāṣya Of Sāyan̄ācārya. Surabaya: Paramita 